\begin{tabular}{|c|c|c|}
\hline & Int.J.Curr.Microbiol.App.Sci (2021) 10(12): 231-239 & \\
\hline & $\begin{array}{l}\text { International Journal of Current Microbiology and Applied Sciences } \\
\text { ISSN: 2319-7706 Volume } 10 \text { Number } \mathbf{1 2} \mathbf{( 2 0 2 1 )} \\
\text { Journal homepage: http://www.ijcmas.com }\end{array}$ & $\$ 0$ \\
\hline $\begin{array}{l}\text { EXCELLENT } \\
\text { PUBLISHERS }\end{array}$ & & \\
\hline
\end{tabular}

\title{
Sensitizing Rural Community on Water Conservation through Whatsapp - An Innovative Extension Approach
}

\author{
Poonam Kundu*, Vandana Verma and Ella Rani
}

Department of Ext. Edu. and Com.Mgt., COHS, Hisar, India

*Corresponding author

\section{A B S T R A C T}

\section{Keywords}

Social Media, Communication, Whatsapp, Awareness and Water Conservation

\section{Article Info}

Received:

11 November 2021

Accepted:

04 December 2021

Available Online:

10 December 2021
Today we are living in a social networking era and the use of social media is a popular trend among people. Social media websites and applications are designed to enable people to share any information in fast and more efficient manner. It is a set of information technology that facilitates interaction and networking. Recently communication technologies and information has sparked the creative incorporation of social media into current pedagogical applications and processes. Social media includes wide range of web-based services and tools that were designed to promote community development through collaboration and information sharing. Keeping the above facts in mind the present study was carried out to create awareness about water conservation techniques through whatsapp messages. For this ten messages were designed and developed on different water conservation techniques. These messages were sent to 40 rural women of Burack and Gawar villages of Hisar district through Whatsapp. Later the effectiveness of WhatsApp messages on water conservation were judged on five different parameters viz; Clarity of printing, font size, Clarity of picture, Appropriateness of language and Usefulness of information. The results highlighted the fact that majority of the respondents $(75 \%-90 \%)$ perceived all the messages as very appropriate in terms of clarity of printing, clarity of picture and appropriateness of language used in the picture. They also perceived them as highly useful and understandable. Hence these messages can be effectively use on whatapp to create awareness about water crisis and how to conserve water at domestic front in rural areas.

\section{Introduction}

Water is arguably Earth's most precious resource, and one of its most scarce. Life without water would not just be inconvenient, it would be impossible. Adequate availability of water is pre-requisite for survival and quality of human life. With about 1.2 billion people without access to drinking water and about 2.4 billion lacking basic sanitation, the symptoms of emerging global water crisis are too obvious. It is projected that the population under water stress will rise from 450 million at present to 2.7 billion by 2025 . It is a natural 
resource that everyone needs to be able to survive. It is being used faster than it can possibly replenish itself naturally. Most people do not think that water will forever disappear, but it is possible. There are many states in our country itself where people have to walk miles and miles to fetch water for their daily chores. It is a sad state of affairs that majority of people carelessly over uses the water supply, and do not try to conserve it. Conserving water will benefit everyone. If everyone conserves water, then it will secure the clean water supply, eventually save water for future generation and most important protect the environment. We could make a great difference if the average use of water that everybody uses decreases even just a little bit; it would still make an overall difference. Recently communication technologies and information has sparked the creative incorporation of social media into current pedagogical applications and processes. Social media includes wide range of web-based services and tools that were designed to promote community development through collaboration and information sharing.

Minhas, S. et al., (2016) enunciated in their study that Whatsapp is an effective and affordable platform of communication. Now a day's people use Whatsapp frequently to remain in touch with their friends and family members. Students use Whatsapp for communication with their friends and family members. They share information, pictures and videos in an easy way. Similar findings was also observed by Purkayastha, N. et al., (2018) that there are no doubts that nowadays WhatsApp is a major part of online communication with a considerable growth rate of users and which almost satisfy the users need in every way like providing instant message delivery, multimedia sharing, realtime audio-video conversation and group messaging etc. Keeping the above facts in mind the present study was carried out to see the effectiveness of whatsapp messages that were designed and developed on different water conservation techniques in order to create awareness about water conservation among the rural women of Haryana with the following laid down objectives.

\section{Materials and Methods}

The study was carried out in Hisar district of Haryana state. Two villages namely Gawar and Burak from block Hisar-II were purposively selected being dry region of Hisar district. The sample was also selected purposively, (20 from each village) comprised of 40 literate rural women who were using whatsapp on their phones.

For the present investigation ten messages were designed and developed on different water conservation techniques. These messages were sent to 40 rural women of Burack and Gawar villages of Hisar district through Whatsapp. Later on the effectiveness of WhatsApp messages on water conservation were judged on five different parameters viz; Clarity of printing, font size, Clarity of picture, Appropriateness of language and Usefulness of information. The frequency and percentage were used to draw the final out comes.

\section{Results and Discussion}

\section{Personal profile of the respondents}

In case of Gawar village, fifty percent of the respondents belonged to 28-37 years of age, followed by sixty percent of respondents belonged to general caste and were earning their lively through agriculture, forty five percent of the ladies studied up to matriculation level and all i.e.100 percent ladies were married. On the other hand in village Burak most of the respondents i.e, were belonged to $18-27$ years of age group, 
from general caste, studied up to matriculation level and were earning their livelihood through agriculture. All the ladies i.e. 100 percent were married.

Effectiveness of WhatsApp messages on water conservation

Effectiveness of WhatsApp messages on water conservation were judged on five different parameters: Clarity of printing/ font size, Clarity of picture, Appropriateness of language, Usefulness of information and Clarity of picture. The data depicted in table two and three highlights the facts that majority of the respondents $(75 \%-90 \%)$ perceived all the messages as very appropriate in terms of clarity of printing, clarity of picture and appropriateness of language used in the picture.

Table.1 Personal profile of the respondents (n-40)

\begin{tabular}{|c|c|c|c|c|}
\hline \multirow{2}{*}{ Variables } & \multicolumn{2}{|c|}{ Village Gawar (n1-20) } & \multicolumn{2}{|c|}{ Village Burak (n2-20) } \\
\hline & Frequency & Percentage & Frequency & Percentage \\
\hline \multicolumn{5}{|c|}{ Age } \\
\hline 18-27 years & 09 & 45.0 & 12 & 60.0 \\
\hline 28-37 years & 10 & 50.0 & 08 & 40.0 \\
\hline 38 and above & 01 & 05.0 & 00 & 0.00 \\
\hline \multicolumn{5}{|c|}{ Caste } \\
\hline SC/ST & 06 & 30.0 & 05 & 25.0 \\
\hline BC & 02 & 10.0 & 03 & 15.0 \\
\hline General & 12 & 60.0 & 12 & 60.0 \\
\hline \multicolumn{5}{|c|}{ Education } \\
\hline Illiterate & 00 & 00.0 & 00 & 00.0 \\
\hline Primary & 01 & 05.0 & 00 & 00.0 \\
\hline Middle & 06 & 30.0 & 07 & 35.0 \\
\hline Matriculation & 09 & 45.0 & 12 & 60.0 \\
\hline Higher Secondary & 04 & 20.0 & 01 & 05.0 \\
\hline Graduate & 00 & 00.0 & 00 & 00.0 \\
\hline \multicolumn{5}{|c|}{ Marital Status } \\
\hline Married & 20 & 100.0 & 20 & 100 \\
\hline Unmarried & 00 & 00.0 & 00 & 00.0 \\
\hline Widow & 00 & 00.0 & 00 & 00.0 \\
\hline \multicolumn{5}{|c|}{ Family Occupation } \\
\hline Labour & 06 & 30.0 & 08 & 40.0 \\
\hline Agriculture & 12 & 60.0 & 12 & 60.0 \\
\hline Dairy and allied & 00 & 00.0 & 00 & 00.0 \\
\hline Caste Occupation & 00 & 00.0 & 00 & 00.0 \\
\hline Service & 02 & 10.0 & 00 & 00.0 \\
\hline
\end{tabular}


Table.2 Effectiveness of WhatsApp messages on water conservation. (Village Gawar)

\begin{tabular}{|c|c|c|c|c|c|c|c|c|c|c|c|}
\hline S.No. & Criteria & $\begin{array}{c}\text { Message } \\
1 \\
\text { Freq. } \\
\text { (\%age) }\end{array}$ & $\begin{array}{c}\text { Message } \\
2 \\
\text { Freq. } \\
\text { (\%age) }\end{array}$ & $\begin{array}{c}\text { Message } \\
3 \\
\text { Freq. } \\
\text { (\%age) }\end{array}$ & $\begin{array}{c}\text { Message } \\
4 \\
\text { Freq. } \\
\text { (\%age) }\end{array}$ & $\begin{array}{c}\text { Message } \\
5 \\
\text { Freq. } \\
\text { (\% age) }\end{array}$ & $\begin{array}{c}\text { Message } \\
6 \\
\text { Freq. } \\
\text { (\% age) }\end{array}$ & $\begin{array}{c}\text { Message } \\
7 \\
\text { Freq. } \\
\text { (\%age) }\end{array}$ & $\begin{array}{c}\text { Message } \\
8 \\
\text { Freq. } \\
\text { (\%age) }\end{array}$ & $\begin{array}{c}\text { Message } \\
9 \\
\text { Freq. } \\
\text { (\%age) }\end{array}$ & $\begin{array}{c}\text { Message } \\
10 \\
\text { Freq. } \\
\text { (\%age) }\end{array}$ \\
\hline \multirow[t]{4}{*}{1} & Clarity of printing & & & & & & & & & & \\
\hline & Very appropriate & $16(80.0)$ & $15(75.0)$ & $15(75.0)$ & $16(80.0)$ & $16(80.0)$ & 17(85.0) & $15(75.0)$ & $16(80.0)$ & $15(75.0)$ & 17(85.0) \\
\hline & Somewhat appropriate & $04(20.0)$ & $05(25.0)$ & $05(25.0)$ & $04(20.0)$ & $04(20.0)$ & $03(15.0)$ & $05(25.0)$ & $04(20.0)$ & $05(25.0)$ & $03(15.0)$ \\
\hline & Not appropriate & $00(00)$ & $00(00)$ & $00(00)$ & $00(00)$ & $00(00)$ & $00(00)$ & $00(00)$ & $00(00)$ & $00(00)$ & $00(00)$ \\
\hline \multirow[t]{4}{*}{2} & Clarity of picture & & & & & & & & & & \\
\hline & Very Clear & 17(85.0) & 17(85.0) & $16(80.0)$ & 17(85.0) & $16(80.0)$ & 17(85.0) & $18(90.0)$ & $16(80.0)$ & $16(80.0)$ & $18(90.0)$ \\
\hline & Somewhat Clear & $03(15.0)$ & $03(15.0)$ & $04(20.0)$ & $03(15.0)$ & $04(20.0)$ & $03(15.0)$ & $02(10.0)$ & $04(20.0)$ & $04(20.0)$ & $02(10.0)$ \\
\hline & Not clear & $00(00)$ & $00(00)$ & $00(00)$ & $00(00)$ & $00(00)$ & $00(00)$ & $00(00)$ & $00(00)$ & $00(00)$ & $00(00)$ \\
\hline \multirow[t]{4}{*}{3} & $\begin{array}{c}\text { Appropriateness of } \\
\text { language }\end{array}$ & & & & & & & & & & \\
\hline & Very Appropriate & $16(80.0)$ & $16(80.0)$ & $16(80.0)$ & $15(75.0)$ & $16(80.0)$ & $16(80.0)$ & $16(80.0)$ & 17( 85.0) & 17(85.0) & $16(80.0)$ \\
\hline & To some extent & $04(20.0)$ & $04(20.0)$ & $04(20.0)$ & $05(25.0)$ & $04(20.0)$ & $04(20.0)$ & $04(20.0)$ & $03(15.0)$ & $03(15.0)$ & $04(20.0)$ \\
\hline & Not appropriate & $00(00)$ & $00(00)$ & $00(00)$ & $00(00)$ & $00(00)$ & $00(00)$ & $00(00)$ & $00(00)$ & $00(00)$ & $00(00)$ \\
\hline \multirow[t]{4}{*}{4} & $\begin{array}{l}\text { Usefulness of } \\
\text { information }\end{array}$ & & & & & & & & & & \\
\hline & Highly useful & $18(90.0)$ & 17(85.0) & $16(80.0)$ & $16(80.0)$ & 17( 85.0) & $16(80.0)$ & $17(85.0)$ & $16(80.0)$ & $16(80.0)$ & $17(85.0)$ \\
\hline & Somewhat useful & $02(10.0)$ & $03(15.0)$ & $04(20.0)$ & $04(20.0)$ & $03(15.0)$ & $04(20.0)$ & $03(15.0)$ & $04(20.0)$ & $04(20.0)$ & $04(20.0)$ \\
\hline & Not useful & $00(00)$ & $00(00)$ & $00(00)$ & $00(00)$ & $00(00)$ & $00(00)$ & $00(00)$ & $00(00)$ & $00(00)$ & $00(00)$ \\
\hline \multirow[t]{4}{*}{5} & Understandability & & & & & & & & & & \\
\hline & Easy to understand & 17(85.0) & 17(85.0) & 17(85.0) & $16(80.0)$ & 17(85.0) & $18(90.0)$ & $18(90.0)$ & 17(85.0) & $16(80.0)$ & $18(90.0)$ \\
\hline & To some Extent & $03(15.0)$ & $03(15.0)$ & $03(15.0)$ & $04(20.0)$ & $03(15.0)$ & $02(10.0)$ & $02(10.0)$ & $03(15.0)$ & $04(20.0)$ & $02(10.0)$ \\
\hline & Not clear & $00(00)$ & $00(00)$ & $00(00)$ & $00(00)$ & $00(00)$ & $00(00)$ & $00(00)$ & $00(00)$ & $00(00)$ & $00(00)$ \\
\hline
\end{tabular}


Table.3 Effectiveness of WhatsApp messages on water conservation. (Village BuraK)

\begin{tabular}{|c|c|c|c|c|c|c|c|c|c|c|c|}
\hline S.No. & Criteria & $\begin{array}{c}\text { Message } \\
1 \\
\text { Freq. } \\
\text { (\% age) }\end{array}$ & $\begin{array}{c}\text { Message } \\
2 \\
\text { Freq. } \\
\text { (\% age) }\end{array}$ & $\begin{array}{c}\text { Message } \\
3 \\
\text { Freq. } \\
\text { (\% age) }\end{array}$ & $\begin{array}{c}\text { Message } \\
4 \\
\text { Freq. } \\
\text { (\% age) }\end{array}$ & $\begin{array}{c}\text { Message } \\
5 \\
\text { Freq. } \\
(\% \text { age })\end{array}$ & $\begin{array}{c}\text { Message } \\
6 \\
\text { Freq. } \\
\text { (\% age) }\end{array}$ & $\begin{array}{c}\text { Message } \\
7 \\
\text { Freq. } \\
\text { (\% age) }\end{array}$ & $\begin{array}{c}\text { Message } \\
8 \\
\text { Freq. } \\
\text { (\% age) }\end{array}$ & $\begin{array}{c}\text { Message } \\
9 \\
\text { Freq. } \\
\text { (\% age) }\end{array}$ & $\begin{array}{c}\text { Message } \\
10 \\
\text { Freq. } \\
\text { (\% age) }\end{array}$ \\
\hline \multirow[t]{4}{*}{1} & Clarity of printing & & & & & & & & & & \\
\hline & Very appropriate & $16(80.0)$ & $15(75.0)$ & $15(75.0)$ & $16(80.0)$ & $16(80.0)$ & $15(75.0)$ & $16(80.0)$ & $15(75.0)$ & $15(75.0)$ & $16(80.0)$ \\
\hline & $\begin{array}{l}\text { Somewhat } \\
\text { Appropriate }\end{array}$ & $04(20.0)$ & $05(25.0)$ & $05(25.0)$ & $04(20.0)$ & $04(20.0)$ & $05(25.0)$ & $04(20.0)$ & $05(25.0)$ & $05(25.0)$ & $04(20.0)$ \\
\hline & Not appropriate & $00(00)$ & $00(00)$ & $00(00)$ & $00(00)$ & $00(00)$ & $00(00)$ & $00(00)$ & $00(00)$ & $00(00)$ & $00(00)$ \\
\hline \multirow[t]{4}{*}{2} & Clarity of picture & & & & & & & & & & \\
\hline & Very Clear & 17(85.0) & $16(80.0)$ & 17(85.0) & $16(80.0)$ & $18(90.0)$ & 17(85.0) & $16(80.0)$ & $16(80.0)$ & $17(85.0)$ & $18(90.0)$ \\
\hline & Somewhat Clear & $03(15.0)$ & $04(20.0)$ & $03(15.0)$ & $04(20.0)$ & $02(10.0)$ & $03(15.0)$ & $04(20.0)$ & $04(20.0)$ & $03(15.0)$ & $02(10.0)$ \\
\hline & Not clear & $00(00)$ & $00(00)$ & $00(00)$ & $00(00)$ & $00(00)$ & $00(00)$ & $00(00)$ & $00(00)$ & $00(00)$ & $00(00)$ \\
\hline \multirow[t]{4}{*}{3} & $\begin{array}{c}\text { Appropriateness of } \\
\text { language }\end{array}$ & & & & & & & & & & \\
\hline & Very Appropriate & $16(80.0)$ & $16(80.0)$ & $16(80.0)$ & 15(75.0) & $16(80.0)$ & $16(80.0)$ & 17(85.0) & 17(85.0) & 15(75.0) & $16(80.0)$ \\
\hline & To some extent & $04(20.0)$ & $04(20.0)$ & $04(20.0)$ & $05(25.0)$ & $04(20.0)$ & $04(20.0)$ & $03(15.0)$ & $03(15.0)$ & $05(25.0)$ & $04(20.0)$ \\
\hline & Not appropriate & $00(00)$ & $00(00)$ & $00(00)$ & $00(00)$ & $00(00)$ & $00(00)$ & $00(00)$ & $00(00)$ & $00(00)$ & $00(00)$ \\
\hline \multirow[t]{4}{*}{4} & $\begin{array}{l}\text { Usefulness of } \\
\text { information }\end{array}$ & & & & & & & & & & \\
\hline & Highly useful & $18(90.0)$ & 17(85.0) & $17(85.0)$ & $16(80.0)$ & 17(85.0) & $16(80.0)$ & 17(85.0) & $16(80.0)$ & $16(80.0)$ & $17(85.0)$ \\
\hline & Somewhat useful & $02(10.0)$ & $03(15.0)$ & $03(15.0)$ & $04(20.0)$ & $03(15.0)$ & $04(20.0)$ & $03(15.0)$ & $04(20.0)$ & $04(20.0)$ & $03(15.0)$ \\
\hline & Not useful & $00(00)$ & $00(00)$ & $00(00)$ & $00(00)$ & $00(00)$ & $00(00)$ & $00(00)$ & $00(00)$ & $00(00)$ & $00(00)$ \\
\hline \multirow[t]{4}{*}{5} & Understandability & & & & & & & & & & \\
\hline & Easy to understand & 17(85.0) & 17(85.0) & 17(85.0) & $16(80.0)$ & 17(85.0) & 17(85.0) & $18(90.0)$ & $16(80.0)$ & $16(80.0)$ & $17(85.0)$ \\
\hline & To some Extent & $03(15.0)$ & $03(15.0)$ & $03(15.0)$ & $04(20.0)$ & $03(15.0)$ & $03(15.0)$ & $02(10.0)$ & $04(20.0)$ & $04(20.0)$ & $02(10.0)$ \\
\hline & Not Understandable & $00(00)$ & $00(00)$ & $00(00)$ & $00(00)$ & $00(00)$ & $00(00)$ & $00(00)$ & $00(00)$ & $00(00)$ & $00(00)$ \\
\hline
\end{tabular}


Table.4 Adoption of water conservation techniques at household front

\begin{tabular}{|c|c|c|c|c|c|}
\hline S.No. & Techniques of water conservation & \multicolumn{2}{|c|}{ Gawar Village } & \multicolumn{2}{|c|}{ Burack Village } \\
\cline { 3 - 5 } & & $\begin{array}{c}\text { Freq. } \\
\text { (n-20) }\end{array}$ & \%age & $\begin{array}{c}\text { Freq. } \\
\text { (n-20) }\end{array}$ & \%age \\
\hline $\mathbf{1}$ & $\begin{array}{c}\text { Minimizing the use of water in daily } \\
\text { household activities }\end{array}$ & 16 & 80.0 & 13 & 65.0 \\
\hline $\mathbf{2}$ & $\begin{array}{c}\text { Recycling of water used for washing of } \\
\text { clothes \& washing of utensils. }\end{array}$ & 16 & 80.0 & 13 & 65,0 \\
\hline $\mathbf{3}$ & Rain water harvesting & 12 & 60.0 & 08 & 40.0 \\
\hline
\end{tabular}

Fig.1 Messages on water conservation
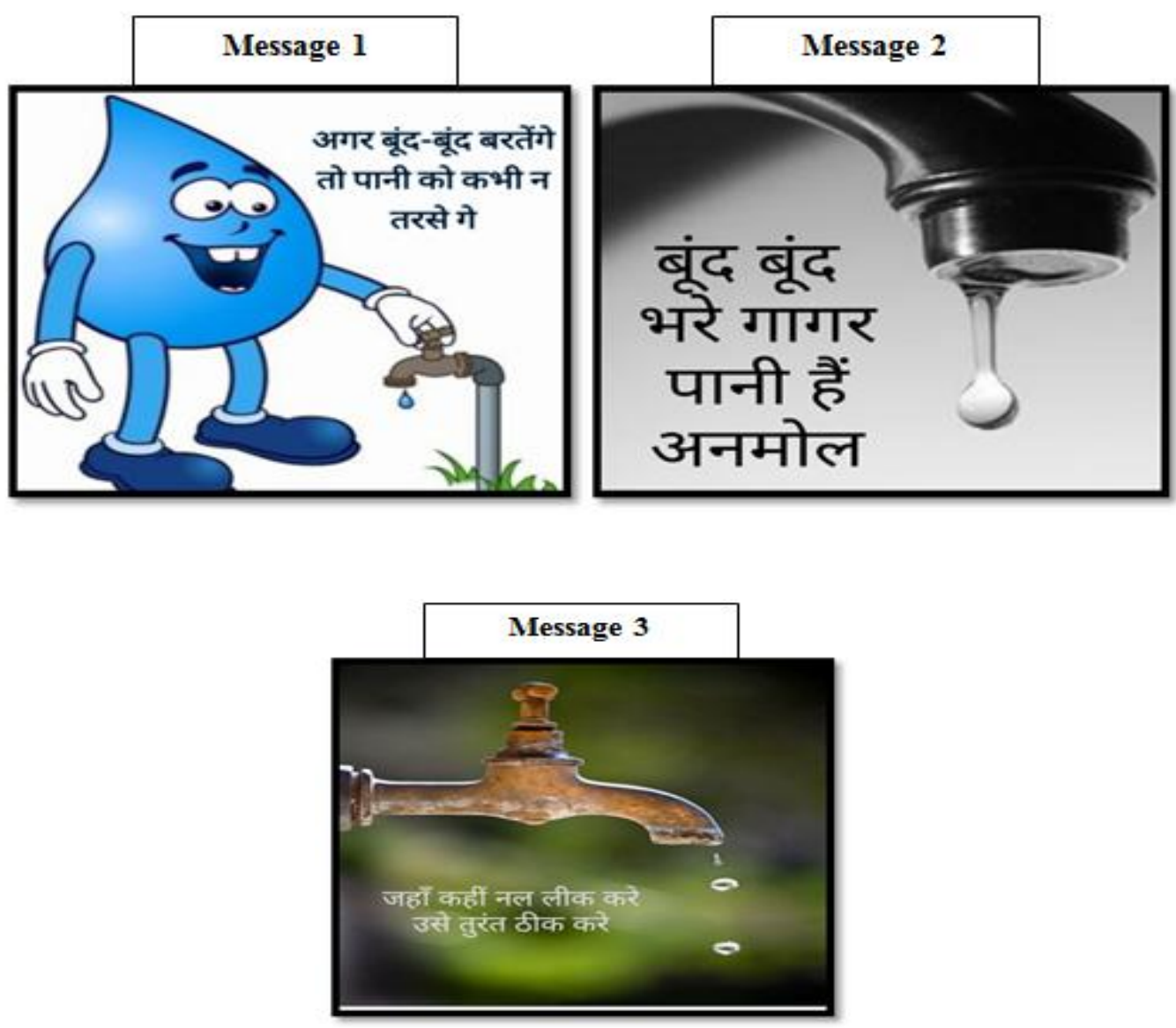

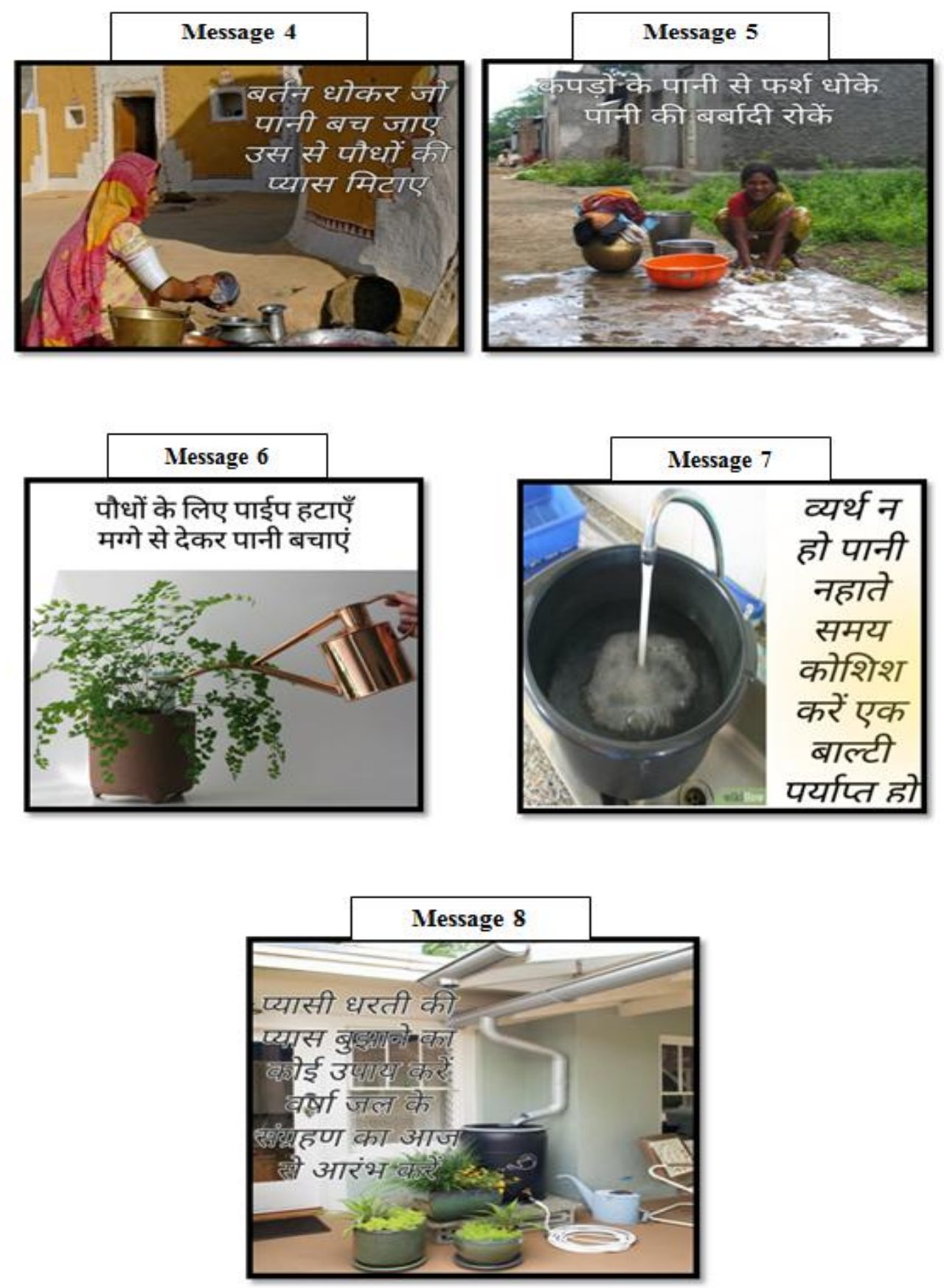

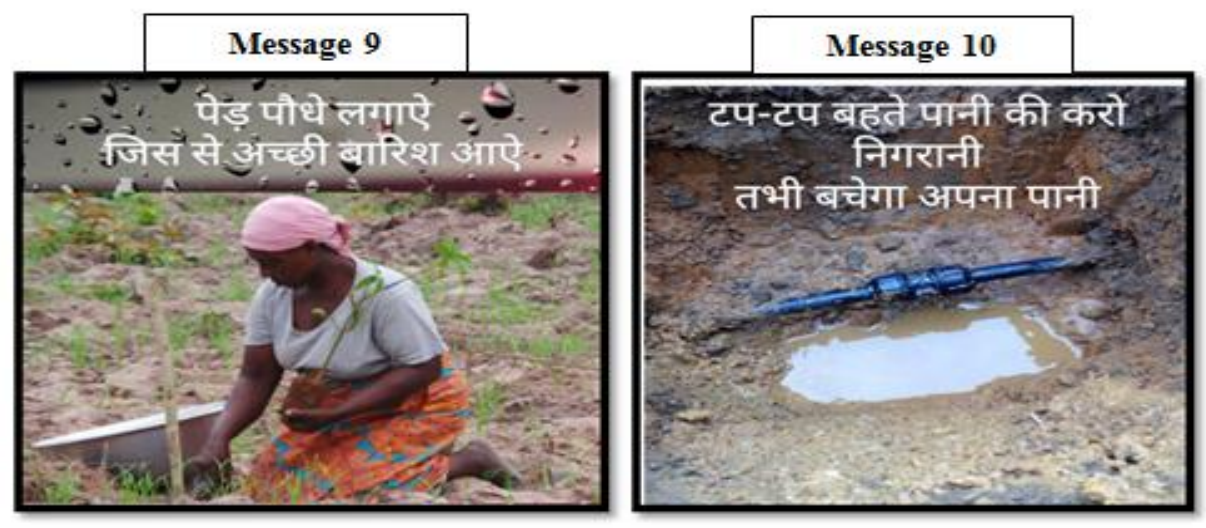

They also perceived them as highly useful and understandable (Table-2\&3). Hence these messages can be effectively use to create awareness about water crisis and how to conserve water at domestic front in rural areas.

Similar finding was also observed by Tandale, M.S.(2018) that WhatsApp is used $100 \%$ as a communication tool for sharing academic information with the friends than other social networking applications.

He further suggested that more researches can be conducted on this topic to find out the usability of WhatsApp messenger with respect to various aspects of the academic environment.

The data accentuate the facts that in village Gawar 80.0 percent and in village Burack 65.0 percent rural rural women have adopted and practicing the water conservation techniques at domestic front. Viz; minimal use of water and recycling of water, whereas water harvesting technique was adopted by 60.0 percent respondents in village Gawar and 40.0 percent in village Burack. Hence it can be concluded that awakening has been created among the rural clientele regarding the importance of water conservation which indicate that whatsapp is a smart and effective extension tool which can be used for creating awareness among the masses.
A step to conserve water is the step to secure the future. The most essential among all the natural resources on earth is water. A drop of water is worth more than a sack of gold for the thirsty man. If each one of us make efforts to save water today, it will save us later. Water conservation is the most effective and environmentally sound method to fight global warming. Water conservation is what that can reduce the scarcity of water.

It aims to improve the efficiency of use of water, and reduce losses and waste. In the present investigation an attempt has been made to see the effectiveness of whatsapp messages that were designed and developed on different water conservation techniques in order to create awareness about water conservation among the rural women folk of Haryana.

The results of the study revealed the facts that all the messages were perceived as very appropriate in terms of clarity of printing, clarity of picture and appropriateness of language used in the picture.

Simultaneously messages were also considered highly useful and understandable. Thus it can be concluded that these messages can be effectively use to create awareness about water crisis and how to conserve water at domestic front in rural areas. 


\section{References}

https://blog.mygov.in/water-conservationrainwater-harvesting

http://www.ecoindia.com/education/waterconservation.html

Nilanjana Purkayastha1 \& Anupam Chanda2 (2018). Whatsapp as a means of sharing information among lis professionals of north-east India: a study impact: International Journal of Research in Applied, Natural and Social Sciences (IMPACT: IJRANSS) ISSN (P): 2347-4580; ISSN (E): 23218851 Vol. 6, Issue 9, Sep 2018, 69-82
Ullah (2016) Usage of Whatsapp: A Study of University Of Peshawar, Pakistan. International Journal of Humanities and Social Science Invention ISSN (Online): 2319 - 7722, ISSN (Print): $2319-7714$ www.ijhssi.org ||Volume 5 Issue 7 ||July. 2016 || PP.71-73.

Tandale, M. S. (2018). Use of WhatsApp as tool for information dissemination in the colleges of western region of Mumbai: A study. International Journal of Information Dissemination and Technology, 8(3), 147-149. ISSN 2229-5984 (P) 2249-5576 (e).

Shahid Minhas, Masroor Ahmed, Qazi farman

\section{How to cite this article:}

Poonam Kundu, Vandana Verma and Ella Rani. 2021. Sensitizing Rural Community on Water Conservation through Whatsapp-An Innovative Extension Approach. Int.J.Curr.Microbiol.App.Sci. 10(12): 231-239. doi: https://doi.org/10.20546/ijcmas.2021.1012.027 